https://doi.org/10.18485/iipe_60nam.2021.ch18

\title{
THE NON-ALIGNED MOVEMENT, NAMIBIA AND SOUTH AFRICA OVER SIXTY YEARS
}

\begin{abstract}
Chris SAUNDERS ${ }^{1}$
Abstract: For much of the first 30 years of the Non-Aligned Movement (NAM)'s existence, the period of the Cold War, no part of what was then called the Third World featured larger on the NAM agenda than Southern Africa. This was because of the continuation of colonial rule and the system of formalised racial oppression known as apartheid, which was applied both in South Africa itself and in the country it occupied, Namibia. The NAM gave strong support to the main Namibian liberation movement, the South West Africa People's Organisation, which was given full membership in 1978. South Africa's African National Congress gained observer status, and the NAM routinely condemned apartheid and called for international action against it. The NAM played only a minor role in the end of apartheid, but after South Africa became a full member in 1994, it was very active in the NAM for a time. Its involvement declined after 2006, as its priorities shifted elsewhere.
\end{abstract}

Key words: Apartheid, South Africa, Namibia, Non-Aligned Movement, African National Congress, South West Africa People's Organisation

\section{The Non-Aligned Movement, Namibia and South Africa over Sixty Years}

For much of the first 30 years of the Non-Aligned Movement (NAM)'s existence, the period of the Cold War, no part of what was then called the Third World featured larger on the NAM agenda than Southern Africa. This was because of the continuation of colonial rule and the system of formalised racial oppression known as apartheid. The NAM routinely called for the

\footnotetext{
${ }^{1}$ Professor, University of Cape Town, South Africa.

E- mail: chris.saunders@uct.ac.za
} 
end of colonial rule and apartheid and denounced South Africa both for its notorious racial policies, which buttressed a white minority in power, and for its continued occupation of the neighbouring territory that South Africa called South - West Africa. From the late 1960s, following the usage of the country's main liberation movement, the South West Africa People's Organisation (SWAPO), the NAM knew the territory as Namibia. ${ }^{2}$ In 1978, SWAPO was accorded full membership in the NAM, which was a status the main South African liberation movement, the African National Congress (ANC) of South Africa, did not achieve in the decades of struggle against apartheid. With the end of the Cold War came the independence of Namibia. The end of apartheid in South Africa followed soon after that. Under majority rule, the new South Africa became a full member of the NAM. With the ANC in power wishing to burnish its credentials in the Global South, South Africa played a major role in the NAM in the late 1990s. Though South Africa continued to be an active member in the early 2000s, South Africa's priorities shifted elsewhere long before 2021.

Southern African leaders were active in the NAM from the establishment of the organisation. Two South African anti-apartheid activists, Molvi Ismail Cachalia of the South African Indian Congress and Moses Kotane of the South African Communist Party and the ANC travelled to Bandung, Indonesia, in 1955 despite the apartheid regime denying them passports to travel. There they attended, as observers, the first Asian-African conference, which they saw as an opportunity to help internationalise the struggle against apartheid and to lobby support for that struggle among the countries in Asia and Africa then emerging from colonial rule. The Memorandum against Apartheid they presented to the assembled delegates received little attention (Lee, 2010). Six years later, the leader of the ANC in exile, Oliver Tambo, who was later to be its president, attended the inaugural meeting of the NAM in Belgrade, Yugoslavia, as an observer. Tambo, who had fled South Africa in March 1960, represented in Belgrade a short-lived United Front in which the ANC then participated, which brought together a number of liberation movements, including the South West African National Union (SWANU) (Thomas, 1996, p. 96). Another attendee at the Belgrade meeting was the founding president of SWANU's rival, SWAPO, Sam Nujoma. He had also gone into exile in early 1960 and

${ }^{2}$ Fortuitously, the organisation and the territory came to share the same abbreviation, 'Nam', once 'Namibia' came into common parlance as the name for the country in the late 1960s. 
had visited Belgrade in March 1961, where Josip Broz Tito promised him support. Nujoma then returned to the Yugoslav capital in September of that year to attend the first NAM conference (Nujoma, 2001, 114-115, 119). He had a different agenda from Tambo, for SWAPO was a nationalist movement, and Nujoma's aim was to rally international support for the campaign for an independent Namibia free of South African rule. Though South Africa applied similar apartheid policies in both South Africa itself and occupied Namibia, SWAPO always saw its struggle as separate from that against apartheid. From the NAM's inception, most of its members were countries that had recently emerged from colonialism and become members of the United Nations (UN). They were strong supporters of the anti-colonial and anti-racist struggles in Southern Africa. As a body of countries that saw themselves as outside the bipolar world of Cold War rivalry, the NAM hoped to play a special role in promoting the interests of the Global South at the UN. Among the NAM's major concerns were Namibia and South Africa. Let us consider them in turn.

\section{Namibia}

Of all the territories that were in the 1960s still under forms of colonial rule - and in South Africa, under white minority rule, the black majority lived under a form of colonial rule - Namibia had a unique status, as the only territory for which the UN, as the successor to the League of Nations, claimed a "special responsibility" because Namibia had been a mandate territory under the League. For more than two decades the NAM paid special attention to the Namibian issue. While the campaign for Namibian independence cannot be divorced from, and was often seen as part of the campaign to end apartheid in South Africa, the Namibians in the liberation movement insisted that their territory was not part of South Africa and therefore that their concerns should not be subsumed in a broader struggle against white minority rule and apartheid. The NAM sought to advance the goal of Namibian independence and advance the legitimacy of SWAPO in the international community.

Nujoma attended all the three-yearly NAM summits of heads of state and governments throughout the almost three decades he spent in exile. Following the ANC, SWAPO took up arms to achieve its ends, and the second NAM summit accepted the right of people to take up arms in support of self-determination and independence (Saxena, 1989). In the 1970s, the NAM played a key role in internationalising the Namibian issue, 
bringing it before both the UN General Assembly and the Security Council and generally supporting SWAPO in its diplomatic campaigns (Saunders, 2016; Karase, 1987; Džuverović, 1989). After the advisory decision of the International Court of Justice in 1971 that South Africa's rule of Namibia was illegal, and that South Africa should withdraw from the territory, the NAM lobbied the UN Security Council to take up the Namibian issue. In 1972, SWAPO was invited to attend a meeting of NAM foreign ministers in Georgetown, Guyana. The following year, as the NAM was becoming more institutionalised, the liberation movement was granted formal observer status (Singham and Hune, 1986, 76; Dinkel, 2018). From then on, SWAPO worked closely with both the NAM's main executive body, the Coordinating Bureau, which was usually made up of the ambassadors of the non-aligned countries that were members of the UN, and the much smaller NAM caucus, comprising those members of NAM who had been elected to the Security Council as non-permanent members. Before they were taken to the General Assembly or the Security Council, draft resolutions were approved by the Co-ordinating Bureau on which SWAPO served. While the Organization of African Unity (OAU) was the first international body to recognise SWAPO as "the authentic representative of the Namibian people", a formulation the NAM accepted at its fourth summit in Algiers in 1973. This was a tribute to SWAPO's more active diplomacy than SWANU's and because alone among the Namibian liberation movements SWAPO had begun an armed struggle (Nujoma, 2001). The NAM successfully pushed for such recognition of SWAPO to be included in a resolution of the UN General Assembly later that year (UNGA Resolution 3111; Dobell, 1998, 42). ${ }^{3}$ The Western powers, led by the US, would not support this, but could not prevent the Namibian issue from coming before the Security Council, where the Soviet Union strongly backed the NAM's position on Namibia. From 1977 the Western powers on the Council took the lead in trying to negotiate a settlement of the Namibian issue, side-lining the NAM. In response, the NAM in October 1978, at an extraordinary meeting of its ministers in New York, accorded SWAPO full membership of the organisation. The NAM ignored a crisis in SWAPO that led to a break-away of those who founded SWAPO-Democrats (SWAPO-D), and its ongoing support for SWAPO helped the liberation movement gain access to other international organisations (Singham and Hune, 1986, 27; Katjavivi, 1986, 339). In September 1979, Cuba became the NAM chair at a summit held in Havana

\footnotetext{
${ }^{3}$ In 1976 this became "sole and authentic".
} 
and sought to take the NAM in a more radical and activist direction. This was strongly backed by both SWAPO and the ANC. Then the "new Cold War" of the early 1980s gave the NAM scope to play a more active role in support of Namibian independence. In February 1981, the NAM foreign ministers, meeting in New Delhi, accused South Africa of duplicity for giving the impression of wanting Namibian independence but subverting the process that would lead to genuine independence (Džuverović, 1989). The NAM rejected the idea, introduced by the US, of linking the independence of Namibia to the withdrawal of the Cuban military force in Angola, and accused the US of attempting "to hijack the Namibian issue outside of the UN system" (Davies, 2007; Singham and Hune, 1986, p. 6). ${ }^{4}$ The NAM redoubled its efforts to exert pressure for an UN-led process to independence for Namibia to be implemented, accepting that this was the most likely way to achieve that goal. While the US and UK governments refused to deal with SWAPO, the NAM sought to advance SWAPO's claim to be a virtual government-in-waiting. ${ }^{5}$ At the seventh NAM summit, held in New Delhi in March 1983 when it seemed that South Africa was about to install a client government in Namibia, Namibia was the main issue discussed. Linkage and "constructive engagement" with South Africa were roundly condemned, comprehensive mandatory economic sanctions against South Africa demanded, and a call made that the Namibian issue be returned to the UN Security Council (Gorbunov, 1988). ${ }^{6}$ At the end of the conference, the member states issued a declaration mandating the chairman of the Co-ordinating Bureau to convey to the UN Secretary-General the NAM's "deep concern" at "the continuing failure to bring about the independence of Namibia and the latest attempts by Pretoria to create a fait accompli" (Non-Aligned Conference, 1983). This message was reiterated when, after a series of attempts in 1984 to bring about a settlement failed, the NAM ministers met in Luanda, Angola, in 1985, and again when a NAM summit was held in Southern Africa for the second time, in Harare, Zimbabwe, in 1986 (Mandaza, 1986, p. 66). There too, Namibia was one of

${ }^{4}$ The aim of the West, they say, was to make Namibia "a pro-Western dependent state".

${ }^{5}$ This was in the context of continuing South African attempts to demonise SWAPO. An example of this was the way it engineered hearings in the US Senate in 1982 that sought to establish SWAPO as a terrorist organisation.

${ }^{6}$ The extraordinary meeting of the NAM Co-ordinating Bureau held in April 1985 was entirely devoted to Namibia. 
the leading items on the agenda. That summit condemned the recently installed Transitional Government of National Unity in Namibia while praising SWAPO for stepping up its armed struggle. It was the winding down of the Cold War, in which the NAM played little role, together with events on the battlefield in southern Angola, that led to the agreement in December 1988 to proceed with the UN plan for a transition to independence in Namibia. In early 1989 the major powers proposed cutting back on the size of the UN mission to be sent to Namibia, and the NAM led the opposition to this, fearing it would embolden the South African government to try to manipulate the election to be held under UN auspices. After much discussion by the NAM's Co-ordinating Bureau concerning the Security Council resolutions on the implementation process of the UN settlement plan for Namibia, the Western permanent members of the Security Council reached an agreement with the three leading countries on the Co-ordinating Bureau, Yugoslavia, Zimbabwe and Zambia, that the UN mission would be cut, but that additional personnel would be held in reserve (Tsokodayi, 2011, p. 620; Thornberry, 2004, pp. 38-40). ${ }^{7}$ The ninth NAM summit, held in Belgrade in September 1989, regretted this compromise, saying it prejudiced the ability of the UN to carry out its mandate to ensure independence through a free and fair election, but the NAM's demand that the reserves be deployed in Namibia got nowhere. The Belgrade NAM Summit claimed that the tragic events of early April 1989, when SWAPO fighters entered Namibia and were killed in large numbers by South African forces, would not have happened had the UN mission been deployed as it should have been, and it condemned the UN for allowing South African forces to act against the SWAPO fighters (Saxena, 1989, pp. 206-207). ${ }^{8}$ Later that year the NAM helped secure the disbandment of South Africa's paramilitary force in northern Namibia. The NAM continued to monitor the process leading to Namibia's first democratic election in November 1989, trying to ensure a free and fair election. After SWAPO won the election, Nujoma, in his inaugural speech as the first President of independent Namibia, did not single out the NAM but

\footnotetext{
${ }^{7}$ Tsokodayi, the Deputy Permanent Representative of Zimbabwe to the United Nations in 1988- 89, was the Deputy Chairman of NAM's Co-ordinating Bureau. As his superior was often away from New York, he acted for the Bureau in the key international negotiations and decision-making process.

${ }^{8}$ The controversy about 1 April turned partly on an interpretation of the Geneva Protocol of August 1988 and whether SWAPO had committed itself to observe it.
} 
expressed the "most sincere gratitude to the international community for its steadfast support". Though Nujoma attended the first NAM summit after Namibian independence in September 1992, his relatively small and underresourced country did not, unlike South Africa, play a leading role in the NAM after independence (Speeches of the President of the Republic of Namibia, 1990). ${ }^{9}$

\section{South Africa}

After the initial Belgrade Summit, the ANC regularly attended summits of the NAM, but never acquired the same status as SWAPO because the NAM would only accept what the OAU had approved, and the OAU recognised both the ANC and its breakaway rival, the Pan-Africanist Congress (PAC). The ANC and PAC vied for international support, and though the ANC won the vast bulk of that support and attended the NAM conferences more frequently than the PAC, it never won recognition as South Africa's only liberation movement. The rise of the Black Consciousness Movement in South Africa in the 1970s added to the reluctance of the OAU and the NAM to accord exclusive recognition to the ANC. As a result, the NAM spoke of South Africa's liberation movements without mentioning any by name, until the final Declaration of the New Delhi Summit congratulated the ANC on Umkhonto weSizwe's "spectacular victories in South Africa's townships" (Thomas, 1996, pp.106110). Though Tambo and other ANC officials were asked to address summit meetings, the ANC could not, as an observer, participate in discussions, and in the ANC there was some resentment at SWAPO's success in attracting so much attention in the NAM. While the ANC was able to lobby at summits and influence debates, the NAM was less important for the ANC in exile than it was for SWAPO. While the ANC was grateful for the rhetorical support the NAM gave, it was often disappointed that the NAM did not go further. At the inaugural Belgrade meeting, the Sharpeville massacre was not mentioned in the final Declaration, while the Lusaka Declaration of 1970 made no specific reference to the armed struggle. While the Algiers Summit in 1973 did give strong support to that struggle in its Resolution on Apartheid and Racial Discrimination in South Africa, the Solidarity Funds the NAM established

\footnotetext{
${ }^{9}$ In 2013, Nujoma did call for a strengthening of the NAM "to withstand the onslaught of foreign forces".
} 
disbursed relatively little compared to the financial assistance the ANC and PAC obtained from, say, the UN or the government of Sweden (Thomas, 1996, pp.101-102; Singham and Hune, 1986, pp. 25-29; SADET, 2008, p. 1282, etc.). The ANC believed in being "non-aligned but committed", and at NAM meetings in 1978 and 1979 in particular it strongly defended Cuba in its anti-Western and pro-Soviet posture, against the Yugoslav view that the NAM should be neutral in the Cold War (Thomas, 1996, pp. 98-100). At the Havana NAM Summit, Tambo spoke first on behalf of all the national liberation movements and then for the ANC. Though the ANC "tried to maintain a diplomatic balance by supporting Cuba and the Soviet Union without alienating the majority of non-aligned states", its impact at the summit "was diminished by the ideological support it gave to Cuba and the Soviet Union" (Thomas, 1996). At the New Delhi Summit in 1983, Tambo again defended Castro, praised the Cuban role in Angola and denounced the US's policy of "constructive engagement" with apartheid South Africa. In the 1980s the ANC became increasingly frustrated with the NAM's impotence. While the NAM continued to denounce the apartheid regime, it played no significant role in South Africa's transition from apartheid to democracy, merely following the OAU in endorsing the Harare Declaration in August 1989, setting out the conditions for a negotiated settlement. Scott Thomas makes the point that this endorsement represented the first time that the NAM had supported the ANC's specific goals; until then it had agreed with the armed struggle in general terms and followed the OAU in calling for South Africa's isolation as a pariah nation because of its policy of apartheid and for the international community to impose mandatory economic sanctions. Though some Western countries imposed sanctions in the late 1980s, the most the UN did was agree, in 1977, to a mandatory arms embargo (Thomas, 1996, p. 105).

\section{After apartheid}

The ending of apartheid coincided with the ending of the Cold War. By the time South Africa joined the NAM as a full member on 31 May 1994, the "classic Belgrade to Belgrade period of non-alignment (1961-1989)" had passed (Fourie and de Villiers, 1998). Some now said that the NAM was anachronistic and irrelevant in the post-Cold War world (Mills, 1997, pp. 160167). As South Africa joined the NAM, the new South African Foreign Minister, addressing the eleventh conference of the NAM foreign ministers in Cairo, made the somewhat exaggerated claim that the NAM had been "at the forefront of efforts by the international community to eradicate 
apartheid". ${ }^{10}$ Now in power, the ANC was keen to promote its anti-colonial credentials on the world stage. Having adopted a strong anti-Western ideological posture during the Cold War, the ANC now saw the NAM as representing the Global South against the industrialised Global North, and as a useful lobby group at the UN for a host of issues relating to developing countries. The new South African Deputy President, Thabo Mbeki, who spoke at the 1995 NAM Summit, called the NAM "a like-minded organisation for joint thinking, planning and action, representing the majority of people and states in the world" (Landsberg, 2010, pp.101-102). Mbeki was keen to "give a new impetus to the NAM", and South Africa was quick to offer to host a NAM summit of heads of state or government (Adebajjo and Virk, 2018, p. 363). It then became the chair of the movement when that summit, the twelfth, took place in Durban from 29 August - 3 September 1998. The South African government hailed this jamboree, on which it spent the large sum of some R50 million, as a major success, but it was hardly the "seminal event in the history of North-South relations" that some had called for (Stremlau, 1998, p. 76, 64). The forty-six heads of State or Government and 70 Ministers of Foreign Affairs attended, together with, for the first time at a NAM summit, representatives of the Group of Eight (G-8) industrial countries and the European Union, for South Africa had hopes of using the NAM to influence the Global North in, say, the future reform of the UN. To meet the concern about what the Nam's priorities should be in the post-Cold War era, the summit mandated a process of identifying these, and, as the NAM chair, South Africa initiated the so-called Zimbali process to review the methodology and organisation of the NAM with the aim of revitalising the organisation (Monyae, 1998; Taylor, 2001, p. 144). After South Africa handed the chair to Malaysia at the NAM Summit in Kuala Lumpur in February 2003, it remained a member of the NAM Troika of past, present and future chairs until September 2006. When South Africa hosted a meeting of the NAM Troika in Cape Town in January 2006, the country's Department of Co-operation and Development put out a statement that the NAM "with 114 member countries, remains the largest political grouping of countries outside of the United Nations itself. In this regard, South Africa has placed a high premium on the membership of this Movement in identifying areas of common concern and support for the implementation of the developmental

${ }^{10}$ Statement by the South African Minister of Foreign Affairs, Alfred Nzo, to the Eleventh Conference of Foreign Ministers of the Non-Aligned Movement Cairo, 31 May-3 June 1994. 
agenda of the South and the African agenda in particular" (Department of International Relations and Cooperations, 2021). But after 2006, as the role of the NAM in international affairs declined, South African interest in the NAM fell away. One sign of this was that after 2006 Dirco's website on the NAM remained updated (Department of International Relations and Cooperations, 2021). South African representatives continued to attend summits and ministerial meetings, repeating the country's gratitude "for the role NAM has played in the decolonisation of our continent and the struggle against apartheid", but other international bodies, such as the Group of 77 developing countries, the India-Brazil-South Africa dialogue forum (IBSA) and from 2010 the Brazil-Russia-China group, which became the BRICS on South Africa's accession, became more important. The BRICS, in particular, offered South Africa vast resource potential. Under Presidents Jacob Zuma and Cyril Ramaphosa, South African foreign policy also shifted to emphasise the country's role on the African continent. A recent large study of South African foreign policy after apartheid barely mentions the NAM (Adebajjo and Virk, 2018).

\section{Conclusions}

The role of the NAM in relation to South Africa and Namibia has both been exaggerated and regarded with too much scepticism. It is an exaggeration to say that "No international grouping has played as significant a role in supporting the rights of the Namibian people and in promoting the independence of Namibia as the Non-Aligned Movement", for the Front Line States, the UN and the OAU played larger roles (Singham and Hune, 1986, pp. 6, 16). But the NAM was not merely a talk-shop that passed resolutions that carried no weight (Crocker, 1992, p. 90). ${ }^{11}$ The NAM summit documents influenced UN resolutions, with the NAM acting as a caucus in the General Assembly. The NAM was a cog in the wheel of international solidarity against apartheid and for the independence of Namibia, helping to inspire those engaged in those struggles to keep going when the odds against their success seemed remote. The moral backing it provided was more important than its modest financial aid. After South Africa became a formal member of the organisation in 1994, following the

${ }^{11}$ The American Assistant Secretary of State for African Affairs in the 1980s wrote dismissively of 'the shrill, all-or-nothing antics of the African-Non-aligned camp, egged on by Moscow's skilful diplomatic apparatus'. 
independence of Namibia and the end of apartheid, there followed a decade in which South Africa played a leading role in helping to shape the organisation. After that South Africa's role became more peripheral, as the significance of the organisation waned, as it was eclipsed by others on the international scene.

\section{References}

Adebajjo, A., Virk, K. (2018). Foreign Policy in Post-apartheid South Africa, London, I.B. Taurus.

Department of International Relations and Cooperations (2021), retrieved from http://www.dirco.gov.za/docs/2006/nam0124.htm, 7.03.2021.

Department of International Relations and Cooperations (2021), retrieved fromhttp:/ / www.dirco.gov.za/foreign/Multilateral/inter/nam.htm, 7.03.2021.

Dinkel, J. (2018), The Non-Aligned Movement: Genesis, Organization and Politics (1927-1992) Leiden, Brill.

Džuverović, O. (1989). The Support for the Namibia Struggle for Independence by the Non-Aligned Movement, in: Chakanyuka Karase and Shadrack Gutto (eds), Namibia: The Conspiracy of Silence, Harare, Nehanda.

Fourie, P., de Villiers, R. (1998). South Africa and the Non-Aligned Movement in an Era of Regionalization and Globalization, Pretoria, Foundation for Global Dialogue.

Gorbunov, Y. (1988), Namibia: A Struggle for Independence: a collection of articles, documents and speeches, Moscow, Progress Publishers.

Karase, C. (1987). The Non-Aligned Movement and the Namibian Question, Review of International Affairs, 38(889), pp. 26-28.

Katjavivi, P. (1986). The Rise of Namibian Nationalism and its International Dimensions, unpublished D. Phil thesis, Oxford, University of Oxford.

Landsberg, C. (2010). The Diplomacy of Transformation . South African Foreign Policy and Statecraft, Johannesburg, Macmillan.

Lee, J. (2010). Making a World after Empire. The Bandung Moment and Its Political Afterlives Athens, Ohio University Press.

Mandaza, I. (1986). Southern Africa and the Non-Aligned Movement' in L.A. Jinudu and Ibbo Mandaza (eds), African Perspectives on NonAlignment. African Association of Political Science. 
Mills, G. (1997). South Africa and the Non-aligned Movement, in: Greg Mills (ed.), South African Yearbook of International Affairs, Johannesburg, SAIIA, pp. 160-167.

Monyae, M.M.D.(1999). South Africa And The Non-Aligned Movement (NAM): Confronting The New Global Challenges', unpublished MA thesis, University of the Witwatersrand.

Non-Aligned Conference. Final Declaration', in Africa Research Bulletin, 1983, 7626

Nujoma, S. (2001). Where Others Wavered, London, Panaf Books, retrieved from http:/ / www.webcitation.org/5y9nJiTzr 7.03.2021.

Saunders, C. (2016). The Non-Aligned Movement, the Neutral European Countries and the issue of Namibian independence, in: Sandra Bott, Jussi M. Hanhimaki, Janick Schaufelbuehl, Marco Wyss (eds), Neutrality and Neutralism in the Global Cold War: Between or Within the Blocs?, London, Routledge

Saxena, S.C. (1989). Namibia in the World, New Delhi.

Singham, A.W., Hune, S. (1986). Namibian Independence. A Global Responsibility, Westport, Lawrence Hill and Company.

Speeches of the President of the Republic of Namibia March 1990-20 March 1995, Windhoek, Ministry of Information and Broadcasting, pp. 233, 463.

Stremlau,J. (1998). The Political Dimension of the African Crisis' in South Africa and the Non-aligned Movement in an era of regionalisation and globalisation, Pretoria, Ministry of Foreign Affairs.

Taylor, I. (2001). Stuck in Middle Gear. South Africa's Post-Apartheid Foreign Relations, Westport, Ct: Praeger.

Thomas, S. (1996). The Diplomacy of Liberation. The Foreign Relations of the African National Congress since 1960, London, I.B. Taurus.

Thornberry, C. (2004). A Nation is born. The Inside Story of Namibian Independence, Windhoek, Gamsberg Macmillan.

Tsokodayi, C.J. (2011). Namibia's Independence Struggle: The Role of the United Nations, Bloomington, Xlibris. 